\title{
Krongodset på Ærø
}

\author{
af Palle Abramsson og Steffen HahnemanN
}

Fra tidligt middelalderlige kilder ved vi, at den danske konge havde omfattende godsbesiddelser på Ærø. I betragtning af Ærøs senere overgang til hertugdømmet Slesvig er det af særlig interesse at følge udviklingen for dette kongelige gods op gennem middelalderen. I artiklen her påpeger forfatterne en markant forskel $\mathbf{i}$ udviklingen mellem de ejendomme, som var kongens arvegods, hans patrimonium, og det gods som var krongods, kongelev, og som derfor principielt skulle følge kongeembedet og ikke være genstand for arvedeling i kongeslægten. Denne forskel i udviklingen for de to kategorier kongsgods består helt frem til slutningen af 1500 -tallet.

Indtil 1331 lå Ærø under den danske krone. I det år blev øen pantsat af kong Christoffer 2. til den holstenske grev Gert, og siden hørte Ærø næsten ubrudt under Slesvig, indtil øen i 1864 igen blev en del af kongeriget Danmark. Allerede i 1749 var Ærø dog blevet samlet under den danske konge, men stadig som en del af Slesvig. I gejstlig henseende lå Ærø imidlertid til stadighed, så langt tilbage kilderne rækker, under bispestolen i Odense.

Fra den tid, før 1331, da Ærø var en del af Danmark, har vi kun ganske få historiske kilder. Den væsentligste er, trods sin kortfattethed, Kong Valdemar 2.s jordebog (KVJ), hvis »Hovedstykke« fra 1231 omtaler kongens gods på Ærø. ${ }^{1}$ Det anføres her at de to næs, de to yderområder, Brunsnæs og Skjoldnæs, er kongelev, d.v.s. krongods, mens resten er patrimonium, d.v.s. kongens arvegods. I jordebogens "Kongelevliste" fra samme tid anføres ligeledes, at Brunsnæs og Skjoldnæs er kongelev. ${ }^{2}$

\section{Kongelev og Patrimonium}

Før vi ser nærmere på disse sparsomme oplysninger, må vi søge at klarlægge de geografiske afgrænsninger på øen af de to kategorier kongsgods i KVJ, kongelev og patrimonium.

En kilde er Johannes Mejers kort fra 1648 (figur 1). Der kan næppe være tvivl om, at Brunsnæs er identisk med østøen, som da var næ- 
Af de nævnte grunde må det antages, at byen Søby har hørt under kongelevet Skjoldnæs.

Udover disse to kongelev må købstaden Ærøskøbing nævnes. Vi ved ikke, hvornår den får købstadrettigheder. Antagelig får den dog status som krongods ca. 1200 samtidig med de øvrige fynske søkøbstæder. KVJ nævner kun undtagelsesvis disse købstæder, skønt de hørte til krongodset på tidspunktet for dens affattelse, så Ærøskøbing kan, skønt unævnt, have været kongelev på KVJs tid.

Fra Slesvig domkirkes regnskaber ved vi, at denne gejstlige institution allerede fra slutningen af 1100-tallet havde betydelige ejendomme på øen. Også St. Knuds kloster i Odense har gods på Ærø før KVJ.s affattelsestidspunkt, og vi har belæg for, at Dalum kloster har ejendomme på øen før 1249. Alt dette gejstlige gods er, hvor kilderne giver os oplysning, lokaliseret til øens midte, hvor kongen anfører beliggenheden af sit patrimonium. Overvejende synes kirke- og klostergodset lokaliseret til Rise og Bregninge sogne (nærmere om det gejstlige gods nedenfor).

Kongen og kronen har således ikke været eneejer af Ærø i 1231. I hvert fald ikke af den del af øen, som er omtalt som kongeligt arvegods.

\section{Markgreverne af Brandenburg}

Udover oplysningerne i KVJ og disse oplysninger om gejstlig ejendom på øen har vi et par skriftlige kilder som dokumenterer, at markgreverne af Brandenburg før 1326 havde omfattende besiddelser på øen. Det ældste af disse dokumenter er fra 1277. Det vedrører en aftale om en - aldrig realiseret - handel med jordegods mellem markgreverne og fyrst Wislaw af Rügen. Bl.a. skulle denne handel indebære, at markgreverne stillede deres gods på Ærø som sikkerhed for et beløb på 1000 mark sølv. Dette gods på Ærø omfatter ifølge texten "Seboy et Grossbol«. 4

Erik Kroman antager, at Brandenburgernes gods var privat ejendom, mens Ærø statsretsligt hørte under kronen. ${ }^{5}$ Det må betyde, at markgreverne kun kunne påregne sig indtægten af fæstegods, og ikke af øens selvejerbønder, som har været "under kronens værn«. Det gejstlige gods på øen har de naturligvis heller ikke haft råderet over.

Det i kilden nævnte Grossbol er os desværre aldeles ukendt. Seboy derimod må betyde Søby, den vestligst beliggende by på øen. Vi ved 
fra 1500-tals kilder, at flertallet af bønderne på det Brunsnæs (=østøen), som i KVJ var angivet som kongelev, overvejende var selvejere ("bunden «), hvad de antagelig også har været på markgrevernes tid. Så de kan ikke have været omfattet af deres besiddelser. Det betyder, at Grossbol må henføres til kongens patrimonium i midtøen. Antagelig er det at forstå som en borg eller tidligere kongsgård med underliggende fæstegods, som altså kun kan have omfattet en del af patrimoniet. Når det formodede kongelev Søby (=Skjoldnæs) nævnes for sig, må det skyldes, dels at den by i sin helhed er i markgrevernes besiddelse, dels at den ikke hører under Grossbol, men indtager en særstilling blandt brandenburgernes ejendomme på øen. Foreneligt med at Søby er synonymt med kongelev'et Skjoldnæs.

Det er nærliggende at antage, at Brandenburgerne er kommet $i$ besiddelse af krongods på Ærø i forbindelse med markgreve Johans giftermål med Valdemar Sejrs datter Sofie, et bryllup som antages at have fundet sted mellem $1232 \mathrm{og} 1235$. At kongen på det tidspunkt skulle afhænde både patrimonium og kongelev er ikke utypisk, og specielt er det upåfaldende på dette tidspunkt så kort efter hans bekostelige frikøb fra fangenskabet hos grev Henrik af Schwerin.

Vi har endnu en kildeoplysning om markgrevernes ærøske besiddelser. Den findes hos historikeren Arild Huitfeldt og henføres af ham til året 1315. Det hedder heri, at Hertug Valdemar af Brandenburg »forlænte Arre lænsvis til Her Laurits Jonessøn oc hans arffuinger, oc skulde hand der aff giffue hannem 100 mark Brandenburgiske mønt til Stralsund. $-{ }^{6}{ }^{6}$

De 100 mark brandenburgsk i årlig afgift svarer, hvis de forstås som mark sølv, nøje til værdiansættelsen på 1000 mark sølv i 1277, for på den tid ansattes den årlige ydelse oftest til $1 / 10$ af ejendomsværdien.

Da den slægtslinie i Brandenburg, i hvis private besiddelse Ærø var, uddør 1320, falder deres gods på øen tilbage til den danske konge, men allerede 1331 pantsættes øen til de schaumburgske grever i Holsten og mister sin forbindelse til den danske krone for lang tid fremover.

\section{Ejendomsforholdene indtil slutningen af 1500-tallet}

For at få et indtryk af udviklingen af krongodset på Ærø, må vi forsøge at kortlægge ejendomsforholdene frem gennem de næste århundreder. 
Ovenfor er omtalt de ældste kildeoplysninger vedrørende Slesvig domkirkes og fynske klostres besiddelser på Ærø. Først mod slutningen af 1500-tallet får vi dog fyldestgørende viden om ejendomsforholdene. Fra den mellemliggende tid har vi kun spredte informationer, væsentligst omfattende klostergodset.

En detailleret redegørelse for besiddelsesforholdene fremgår af nedenstående Addendum. Det fuldstændige overblik over gejstligt og adeligt gods fører tilbage til tiden for reformationen. Vi har som anført nogen indsigt $i$, hvornår det gejstlige gods på øen er etableret. Vedrørende de adelige besiddelsers opkomst er vi imidlertid på usikker grund, men også de er antagelig overvejende etableret i katolsk tid.

Det samlede omfang af klostergods og adelsgods er på 94 gårde. Dertil kommer gods henlagt til præsters underhold (mensalgods) og gods tilhørende kirker og hospitaler på mindst 10 gårde, som øger tallet til 104. Det vil sige, at ca. 1/3 af alle gårde på øen ved reformationen må antages at have været på klostrenes eller adelens hænder.

Oversigten viser desuden, at omfanget af klostergods og adelsgods tidligere har været endnu større, vel op mod 125-130 gårde. Det er dog ikke alt dette gods, vi kender den præcise beliggenhed af.

\section{Fordelingen af det gejstlige og adelige gods}

Fordelingen af gejstligt og adeligt gods på ejerlavene ved reformationen eller ved hertug Hans den Yngres overtagelse af Erø fremgår af figur 2.

Det må betegnes som påfaldende, at ingen af gårdene på østøen (Marstal sogn), i Søby eller i Stokkeby synes at have været på gejstlige eller adelige hænder. I Stokkeby er kun den ærøske lavadelsmand Mats Lud (måske fejlagtigt) anført for en gård, ellers har det ejerlav også været uberørt af adel eller gejstlighed. Disse byer rummer tilsammen næsten en tredjedel af $Æ$ Erøs gårde, som altså formentlig aldrig har været afhændet fra øens kongelige eller fyrstelige overhoved (se dog ovenfor vedr. markgreverne af Brandenburg). Det gejstlige og adelige gods på tilsammen 104 gårde var udelukkende lokaliseret til øens centrale område. Tidligere har det været mere omfattende, og hvor vi har præcise oplysninger, ses dette gods også at være lokaliseret til centralområdets byer.

Der synes således at være en markant forskel på udviklingen mel- 
Olirde / Adel- kloster- of klrkegods

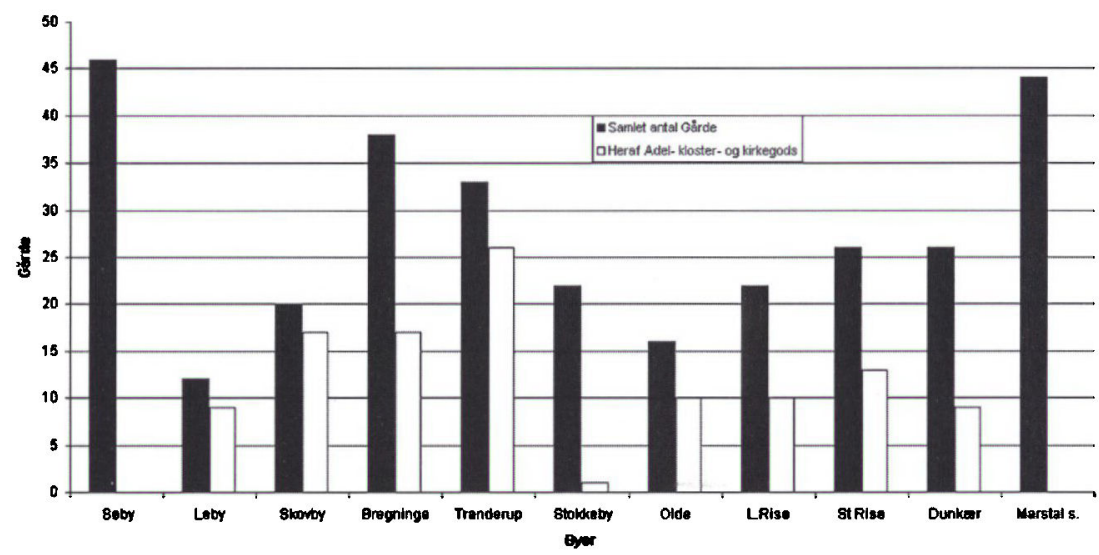

Figur 2. Anparten af kloster-og adelsgods $i$ hver af Ærøs byer.

lem periferi og centrum. Ca. halvdelen af gårdene i centralområdet er afhændet til klostre eller adel, mens alle gårdene på østøen og vestøen fortsat ligger til den slesvigske fyrste (som i lange perioder var den danske konge). Disse to periferi-områder er antagelig identiske med kongelevene i KVJ, og det er nærliggende at henføre denne »uafhændelighed « til disse områders kongelev-status.

Byen Stokkeby med 20-22 gårde falder tilsyneladende udenfor disse rammer. Vi har ingen helt tilfredsstillende forklaring på, at denne by adskiller sig fra de andre byer $\mathrm{i}$ patrimonium. Men årsagen kunne være den, at Stokkebys gårde udviklingsmæssigt er tæt knyttet til Ærøskøbing og formentlig oprindelig har sognet til kirken dér. ${ }^{7}$ Det kunne betyde, at den sammen med byen har været kongelev, sådan som alle købstæder var fra et tidligt tidspunkt. ${ }^{8}$ (Se figur 3).

Forholdet mellem Stokkeby og Ærøskøbing berøres flere steder i overleveringen. Ifølge Hofmanns fundatser havde Ærø oprindelig kun 3 sogne, nemlig Rise sogn, Bregninge sogn og Ærøskøbing sogn, mens det 4., nemlig Tranderup sogn, først kom til senere. Situationen har dog snarere været som anført i Pontoppidan-Hofmans atlas VII, 448 , at Tranderup kirke indtil reformationen var annexkirke til Ærøskøbing. Hofmann hævder, at Stokkeby oprindelig lå til Ærøskøbing kirke. Hübertz gengiver et gammelt Ærø-sagn, som nævner, at præsten i Rise kirke vandt Stokkeby fra præsten i Ærøskøbing i kortspil. ${ }^{9}$ Kortspil eller ej, så kunne overleveringen tyde på, at der på et tids- 
punkt, måske ved reformationen, er sket en overførsel af Stokkeby fra det ene sogn til det andet.

Om Erøskøbing ved vi fra et tingsvidne fra 1398, at byen (som da kaldtes Visby) da havde borgmester og rådmænd og altså har haft købstadstatus ( 2 bønder fra Slæbol i eller ved Stokkeby er da antagelig tingsvidner udpeget for Ærøskøbing sogn). Hvornår byen for første gang får købstadsrettigheder, ved vi ikke, men det er altså før den tid.

Disse enkeltheder kunne tilsammen give formodning om StokkebyVisby/Ærøskøbings status af kongelev, og det kunne være baggrunden for, at heller ikke Stokkeby har haft adelige eller gejstlige ejere.

Fra 1460 til 1564 er Ærø på den danske konges hænder, i hans egenskab af hertug af Slesvig og Holsten. Christian 3. delte Slesvig og Holsten med sine to brødre Adolf og Hans den Fldre. Efter Christian 3.s død bliver hans tredjedel i 1564 delt ligeligt mellem hans to sønner, Frederik 2. og den yngre broder Hans »den yngre«. Det blev Hans som fik Ærø. Dog forbeholdt Frederik 2. sig det klostergods, som ved reformationen var hjemfaldet til kronen, samt noget adelsgods, som Christian 3. var kommet $i$ besiddelse af ved mageskifte. Dette gods er specificeret i Addendum. Sammen med kirkernes mensalgods udgjorde det, som anført ovenfor, 104 gårde. Frederik 2. fastholdt desuden den gejstlige jurisdiktion over de to øer Als og Ærø. I 1584 opstår en ny situation - efter hertug Hans den Ældres død hvor endnu $1 / 3$ af det fyrstelige gods i Slesvig og Holsten kom til deling mellem Frederik 2., hertug Adolf og hertug Hans den Yngre. De aftalte et mageskifte, hvorved bl.a. det anførte kloster- og adelsgods endelig overfores til hertug Hans. Men den gejstlige jurisdiktion fastholdt Frederik 2. under den danske krone. ${ }^{10}$

Som det fremgår af figur 4, er det gods, som hertug Hans ikke umiddelbart kommer i besiddelse af, lokaliseret til det såkaldte patrimonium i midtøen, mens de perifere områder, kongelevene, er uden kloster- og adelsgods og derfor overtages uden indskrænkninger af hertug Hans.

Hans den Yngre tog med stor energi fat på en reorganisering af sine besiddelser, herunder også Ærø. Han etablerede tre hovedgårde på øen med betydelige enemærker og dermed også et belastende hoveri. Størstedelen af reorganiseringen synes at have fundet sted i slutningen af 1570-erne, som det fremgår af hertug Hans' svar fra 1609 på en klage fra kordegnen i Bregninge. Degnen beklager sig over at have mistet degnekorn fra 40 bol (=40 gårde), og hertugen svarer: 


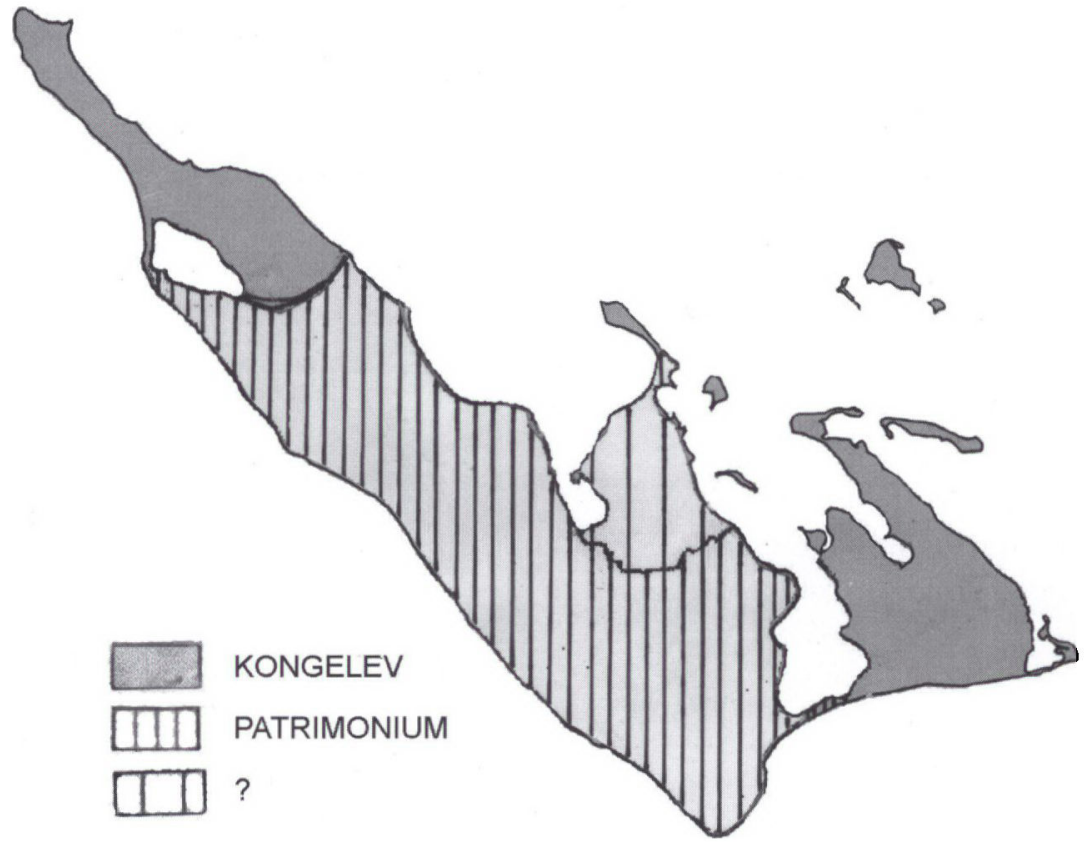

Figur 4. På kortet er angivet forekomsten af kloster-og adelsgods på Erø $i$ relation til øens patrimonium og kongelev. Kongelevet Skjoldenæs indbefattende Søby ejerlav. Stokkeby/Arøskøbing-området som muligt kongelev.

"Der Küster zu Brenninge klaget, das Thnen von 40 bohlen noch 40 skip korn nachstehen sollen. Darauff ist dieser bericht, das seither [herzog Hans] den hoff Sebuigarde erbauett, wngefehr vor 30 jahren, die bohle daselbst vorendrett, wnd die kleinen den grossen gleich gemacht, etliche auch von [herzog Hans] wüste geleget, derowegen der Köster sein schip korn nach anzahl voriger bohle nicht zu fordern, auch dieser sein forderung nun so lange zeit her nicht in geringesten gedacht. «11

Det vil sige, at hertugen i tiden omkring 1579 har ladet nedlægge ikke mindre end 40 gårde i Bregninge sogn og ladet andre gøre ens $\mathrm{i}$ størrelse.

Øens ældste jordebog er fra året $1627 / 28 .{ }^{12}$ Den er blevet til under hertug Hans' søn Christian, som da har overtaget øen efter hertug Hans' død i 1623. Af denne jordebog fremgår det, at gårdene i Søby, Stokkeby og alle byerne i østøen er blevet gjort ens i størrelse/egaliseret (Truelslycke og Dreiby er nedlagt og deres jorde inddraget under hovedgården Gudsgave). Dette i modsætning til de øvrige bylav. Det 
vil sige, at hertug Hans har ladet de byer egalisere, hvis gårde ved delingen i 1564 uden indskrænkning er kommet i hans besiddelse. De øvrige byer, hvis kloster- og adelsgods først kommer i hans besiddelse mellem 1584 og 1590, er ikke blevet egaliserede.

\section{Selvejerbønder}

Selvejergårdene på øen har Erik Kroman interesseret sig for i forbindelse med en analyse af de oplysninger om Ærø, som findes i Kong Valdemars jordebog (KVJ). ${ }^{13}$

Oplysningerne om kongelev og patrimonium på Ærø er ovenfor omtalt. Derudover meddeler jordebogen, hvilke afgifter øen præsterer. Jordebogen beretter følgende:

"Erræ - - XXX mr. annone. X mr. argentii et III $\mathrm{mr}$. ordei et unam mr tritici (oversat:: 30 mark korn, 10 mark sølv og 3 mark byg og en mark hvede).

Erik Kroman hæfter sig ved, at ifølge et regnskab for øen fra 1518 yder øens selvejerbønder da tilsammen 28 mark penge. ${ }^{14}$ Han mener, at denne samlede selvejerydelse er identisk med de 10 mark sølv, som er anført som Ærøs pengeafgift i KVJ, ud fra følgende regnestykke: 1 mark sølv $=45 \mathrm{sk}$ lybsk; 10 mark s $ø l v=450 \mathrm{sk}=28$ mark $2 \mathrm{sk}(1$ mark $=$ 16 sk). Kroman tænker sig derfor, at denne gruppe selvejere i 1518 udgør kongelevet Brunsnæs fra KVJ, der yder de 10 mark sølv som en ledingsafgift.

Der kendes tre lister mellem 1533 og 1544, hvor selvejerafgiften af de omtalte selvejere er specificeret. ${ }^{15}$ Den samlede ydelse er her lidt vekslende. Ser vi bort fra to navngivne selvejergårde og holder os til den gruppe selvejere, som står for de 28 mark penge i 1518, så svinger den mellem $26 \frac{1}{2}$ mark 2 sk og $31 \frac{1}{2}$ mark 2 sk.

Disse selvejere ("Bunden«) udgøres af 27 fra østøens byer Ommel, Kragenæs, Marstal og Dreiby og to fra Stokkeby. Men der er, som det fremgår af samtidige skattelister, på østøen (Brunsnæs) en del bønder, som ikke yder denne bundenafgift. Det drejer sig om de to bønder i Truelslycke, 6-7 gårde i Ommel, 3 gårde i Kragenæs og 5 gårde i Marstal - $\mathrm{i}$ alt 16-17 gårde.

Antagelig er det i forbindelse med ovenfor omtalte egalisering, at gårde på østøen og i Stokkeby, som var selvejere endnu i 1544, i 1627 ses at være blevet reducerede til almindelige fæstegårde. 


\section{Andre selvejerbønder}

Hvad vi derefter ser af bondeselveje er karakteriseret ved en blanding af »bunden«-jord og fæstejord, som det var almindeligt for bøndernes ejendomsforhold i Slesvig. ${ }^{16}$ Disse "bunden« adskiller sig, hvad afgifter angår (incl. hoveri!), kun fra fæstebønder ved ikke at betale stedsmål (indfæstningsafgift) af deres selvejerjord. De yder således ikke, som 1500-tallets selvejere, en særlig pengeydelse (ledingspenge?). Dette selveje er i ovrigt, som vi ser det i begyndelsen af 1600-tallet, på hastig retræte. Vi ser eksempler på, at bonden afgiver sin selvejerjord til fyrsten mod at blive fritaget for hoveri eller landgilde for en kortere årrække (8-10 år). Tilbage er i slutningen af 1600-tallet kun 5 bønder med overvejende selvejerjord. Derudover ser vi små lodder af selvejerjord fordelt på et mindre antal kådnere som et resultat af arvedeling. Alle de selvejere og den selvejerjord, vi støder på i 161700-tallet, er lokaliseret til midtøen, altså til området for KVJ.s patrimonium. ${ }^{17}$

Denne form for selveje, som i øvrigt er velkendt andre steder $i$ Slesvig på den tid, kan have været mere udbredt tidligere. Det omfattende hoveri, som forst og fremmest var begrundelsen for at give afkald på selveje, bliver indført på øen med etableringen af tre hovedgårde, Søbygaard, Gråsten og Gudsgave fra slutningen af 1570-erne. Vi får først med bevarede tingsvidner efter 1630 kilder til belysning af selvejernes overgang til fæste. Der kan være flere, som i de forudgående 50-60 år har truffet det samme valg.

\section{Konklusion}

Undersøgelsen har vist, at der er en markant forskel på ejendomsforholdenes udvikling i øens midterste del og dens perifere områder sammenfaldende med lokalisationen af henholdsvis kongens arvegods (hans patrimonium) og krongodset (kongelev). Kongens patrimonium er fra tidlig middelalder og frem til 1500-tallet i stort omfang overgået til kloster- og adelsgods, mens kongelevene ubeskåret forbliver i fyrstens (kongens eller hertugens) besiddelse. En tidlig donation, antagelig en medgift ved giftermål med Valdemar Sejrs datter, til markgreven af Brandenburg rummer dog både den del af kongens patrimonium, som ikke er afhændet til anden side, eller er selveje, og Søby, som antagelig er identisk med kongelevet Skjoldnæs, men også 
her fremstår kongelevet Søby (Skjoldnæs) som en enhed under én ejer.

Gennemgående kan det konkluderes, at de to kongelev ikke opsplittes, og de overgår da også ubeskåret til hertug Hans ved arvedelingen i 1564, hvor det tidligere klostergods og en del adelsgods endnu ikke kommer i hans besiddelse. Derfor er det kun gårdene i kongelevene, han kan egalisere i sin rekonstruktion af øen i slutningen af 1570-erne.

Ca. 2/3 af gårdene i kongelevet Brunsnæs samt to bønder i Stokkeby er selvejere i regnskaber fra 1518-1544. Kun de af samtlige Ærøs bønder betaler »bunde«-skat, en pengeafgift. Ca. 1/3 af bønderne $i$ Brunsnæs yder dog ikke »bunde«-skat.

Stokkeby fremtræder $\mathrm{i}$ sine ejendomsforhold ligesom de to periferiområder. Måske fordi den udviklingsmæssigt er tæt forbundet med Ærøskøbing, som må have været kongelev fra et tidligt tidspunkt, måske allerede på KVJ.s tid, skønt byen ikke er anført i jordebogen. Søkøbstæderne på Fyn er antagelig alle anlagt mellem 1150 og $1350{ }^{18}$ I den ældste kilde (fra 1398), hvor byen omtales, kaldes Ærøskøbing for Visby.

Der kan i 1600-tallet påvises en anden type selvejergods på Ærø, lokaliseret til området for kongens patrimonium. Det drejer sig om bønder, som typisk har både selvejerjord og fæstejord. De yder afgifter og hoveri som fæstebønderne, den eneste forskel er, at de ikke yder stedsmål. De yder således heller ikke den ovenfor omtalte bunden-afgift. Har de eksisteret også i første halvdel af 1500-tallet, og det er vanskeligt at forestille sig, at det ikke skulle være tilfældet, så beskattes de da anderledes end de omtalte bunden på østøen.

Når østøen er fri for kloster- og adelsgods, så kunne det skyldes det omtalte selvejerforhold. Men dette selveje gælder kun for ca. 2/3 af gårdene. Resten af gårdene på østøen ville altså ikke være beskyttet mod afhændelse af den grund. Men det gælder for det samlede bøndergods på østøen, at det forbliver ubeskåret i fyrstens besiddelse. I Stokkeby er kun 2 af 22 gårde selvejere, og alle gårdene i Søby er fæstegårde. Det er således ikke selvejet i sig selv, som beskytter østøen samt Søby og Stokkeby mod at gårde afhændes.

$\mathrm{Vi}$ begyndte denne artikel med at ræsonnere os frem til, at kongelevene på Ærø bestod af østøen (=Brunsnæs), Søby (Skjoldnæs) og fra et tidligt, men ukendt tidspunkt Ærøskøbing (Visby), som ikke er nævnt i KVJ, men som købstad kunne være implicit til stede. At hæv- 
Figur 5. Kort over Saby bymark med angivelse af den lokalitet, som er benæunt "Bystedet $i$ kilder fra 1774. Den kunne henvise til en oprindelig beliggenhed af Soby. Voldstedet "Borren" ved Søbygård angivet.

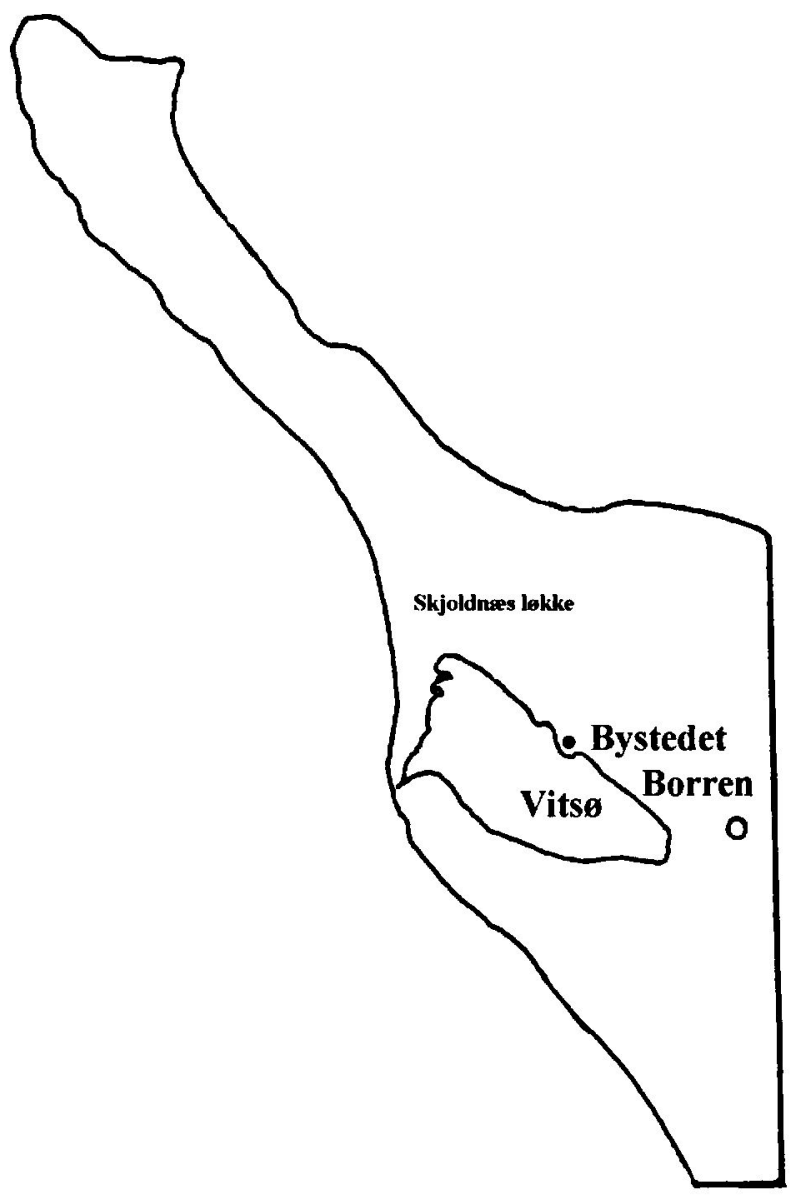

de nu, at denne status af kongelev er grunden til, at gårdene i disse områder ikke afhændes, eller at ejerforholdet ikke opsplittes, antager vi som den mest sandsynlige forklaring på den markante forskel i ejendomsforholdenes udvikling over middelalderen mellem periferi og centrum på Ærø.

Patrimoniet består af øens ældste bebyggelse med bl.a de to -ingebyer Bregninge og Risinge (ældre navn for Lille Rise). De ligger tilbagetrukket på øen, i en defensiv placering bag de skovbræmmede kyster. Kongelevene er antagelig udviklet som led i en mere offensiv linie i forhold til venderne og andre slaviske stammer i Nordtyskland og består 
af kongens skattebønder tillagt en kollektiv ledingsforpligtelse. ${ }^{19}$ Det drejer sig bl.a. om de eneste vikingetidsbebyggelser på øen med suffixet -by: Søby, Stokkeby + Visby, det oprindelige navn for Frøskøbing, og Dreiby (på østøen, nedlagt ca. 1600). De har alle relation til øens borganlæg: Søby til borganlægget ved Søbygaard, måske endda i en oprindelig tættere relation (se figur 5), Stokkeby og Visby i relation til »Styltenborg « (se figur 3) og Dreiby i relation til det dog antagelig noget yngre »Absalonsborg « ved den østlige ende af Drejet. ${ }^{20}$

\section{Addendum. Kloster- og adelsgods på Ærø}

A: Gejstligt gods

Det gejstlige gods på Ærø var af stort omfang og kan, i hvert fald for en dels vedkommende, dokumenteres at være etableret tidligt:

Slesvig domkirkes besiddelser:

Det fremgår af Slesvig domkirkes regnskab fra 1352, at kapitlet dengang havde betydelige besiddelser på $Æ r ø .{ }^{21}$ Under "Bona communitatis capituli Slesvicensis « anføres 7 bønder i Bregninge, som tilsammen giver 24 ørtug $=1$ læst byg $i$ landgilde.

Under »reditum designatio er anført, at »vicaria domini ducis Jucie« har $1 \frac{1}{2}$ læst byg af Ærø og fordum 3 læster. Ducis Jucie er formentlig St. Cannutus (Knud Lavard).

Under kapitlets samlede indtægter anføres, at biskop Valdemar af Slesvig har testamenteret kapitlet 23 mark jord i Rise, Tranderup og Bregninge sogne på Ærø, som giver 25 ørtug byg og forhen måske det dobbelte eller $2 \frac{1}{2}$ mark korn (=60 ørtug).

Denne kraftige nedgang i landgilde er vel så antagelig den eneste dokumentation vi har for, at den sorte død heller ikke er gået Ærø forbi.

Valdemar var biskop i Slesvig i slutningen af 1100-tallet. Han var illegitim søn af den Kong Knud Magnussen, som blev dræbt ved trekongemødet i Roskilde. Han hørte således til kongeætten, og det er vel derfor, han har været $i$ besiddelse af en del af patrimoniet.

Ved reformationen er Slesvig domkapitels gods indskrænket til kun at omfatte 7 gårde, som ligger til kongens kapel. At dette gods også tidligere var i domkapitlets besiddelse bekræftes ved et tingsvidne af Erø landsting d. 17. marts 1476, hvori det dog ikke specificeres. ${ }^{22}$ Det 
er endvidere anført $i$ en jordebogsliste fra 1514 med 1 gård i Bregninge, 1 i Skovby og 5 i Olde. Det er sandsynligt, at dette gods er at finde blandt de 10 gårde, som Jacob Brockenhuus senere er $i$ besiddelse af og i 1555 mageskifter med Christian $3 .^{23}$

At Dalum Nonnekloster havde gårde på Ærø fremgår af et værnebrev på klostret, hvori Pave Innocens 4. i år 1249 bemyndiger Rudolph canonicus i Ribe til at føre sag mod forskellige personer, der havde forurettet nonnerne i Dalum kloster og øvet vold på deres gods på Fyn, Tåsinge, Langeland, Ærø, Als, Femern og Lolland. ${ }^{24}$

Desuden ser vi $i$ et diplom fra 1395, at Dalum kloster har en indtægt på 2 øre byg af jord i Rise sogn på Ærø, og i 1533 ligger følgende fæstebønder til klostret: 1 i Dunkær, 2 i Risinge (Lille Rise), 2 i Rise, 1 i Bregninge og 7 i Tranderup. ${ }^{25}$ Dette gods mageskiftes i 1551 med kronen. ${ }^{26}$

St. Knuds kloster har i 1226 fået bekræftet sine besiddelser rundt om i landet, herunder på Ærø, af pave Honorius III. ${ }^{27}$ I 1377 får klostret af bispen i Ribe bekræftet sin patronatsret til Rise kirke, og afslører sig også i et dokument fra 1471 som godsbesidder på Ærø. I 1533 har klostret 3 gårde i Leby, 2 i Skovby, 4 i Risinge (Lille Rise), 3 i Dunkær, 10 i Rise, 1 i Olde, 1 i Tranderup og 2 i Vuderup. ${ }^{28}$ Dette gods er siden 1543 pantsat til Johann Reuentleff. ${ }^{29}$

Holme kloster - det senere Rantzausminde/Brahetrolleborg - har samme år 1533: 6 gårde i Bregninge by med 3 stykker jord, der hidtil havde hørt til den ene af gårdene, men nu bruges for en årlig afgift af en bonde under Sønderborg slot, samt 11 gårde i Skovby (af et register fra 1572 fremgår det desuden, at klostret, udover de 17 gårde, havde 11 kådboer, som hver betalte 12 skilling. ${ }^{30}$ )

Alt dette klostergods er ved reformationen forfaldet eller overgået til kronen. Ved delingen 1564 fastholder Frederik 2., at det er hjemfaldet til den danske krone og derfor ikke vedrorer delingen af den hertugelige arv $i$ Slesvig og Holsten. Det forer til en langvarig strid med hertug Hans den Yngre, som først slutter $i$ 1584, da hertug Hans den Aldres død baner vejen for et forlig mellem de to brødre $i$ forbindelse med de derved ledigblevne sønderjyske områder.

Helligåndsklostret $i$ Fåborg får 1492 skænket en gård i Tranderup af væbneren Anders Madsen af Lud-slægten på Ærø, for messer. Klo- 
stret havde gårde på Fyn, Als og Ærø, som de 1509 mageskifter med kong Hans, heriblandt den næunte gård i Tranderup, som de fik 1492. Et notat: Godz er kommen fram Faaborgh Closter i Fien och bleff lagt wnder Sunderborgh, som war wdi ...? V gaarde, giffuer: $33 \frac{1}{2}$ ortug biug och Haffre, 8 giess 7 hønss, 11/2 mark 1 sk. ${ }^{31}$

Et andet notat sammesteds: Ithem kom fra Sancte Hansis Closter wdi Othense noget godz paa Erre wdi Jørgen Bradis thidt - och bleff lagt wnder Synderborch. En fodnote oplyser: $» 3$ hoffe lig daselbst(?) hab ein Anfeldt gtz(?), haben aber, bey mensch gedencken, zum Closter nicht gehört, wie er dazu gekommen, hatt man nicht erfrag können. ${ }^{32}$ Der kan altså være tvivl om klostrets adkomst.

Kong Hans har ved et mageskifte med Odensebispen overtaget 8 gårde i Rise sogn. ${ }^{33}$

Disse gårde er dog herefter, som verdsligt gods, ikke berørt af reformationen, og de overdrages til Hertug Hans d. Yngre ved delingen $\mathbf{i}$ 1564.

Desuden anføres en gård i Risinge (Lille Rise) at have hørt under bispegården Ørkil i Svendborg og en gård i Bregninge at have ligget til St. Albans kirke $i$ Odense. ${ }^{34}$

Derudover er der i 1579, og formentlig ved reformationen, nogle kirketjenere på Ærø, der svarer herlighed til kronen og landgilde til kirken og præsten i Rise sogn: 2 i Dunkær, 1 i Torup, 1 i Olde, 1 i Rise, 2 i Tranderup og 1 i Bregninge. 2 kirketjenere i Bregninge svarer deres landgilde til kapellanen i Sønderborg. Heller ikke disse gårde kan hertug Hans således disponere over efter delingen i 1564.

\section{B. Adelsgods}

Den danske adel:

Allerede i 1200-tallet ser vi, at adelen har strøgods på Ærø, som det fremgår af følgende eksempel:

Næstved d. 25. juli 1268: Oluf Rostok, Oluf Ranesen m.fl. bevidner, at Peder Udnyrdingen har pantsat to gårde på Frø til Roskilde Clare kloster, dog således, at de nævnte gårde udløser sig selv gennem deres årlige frugter. ${ }^{35}$ 
Ca. 1500 sælger adelsmanden Anders Tegemantt (Tidemand - høvedsmand på Tranekær slot på Langeland 1495) til Holm 7 gårde samt en øde jord på Ærø til kong Hans. ${ }^{36}$ Godset har Anders Tidemand overtaget efter forudgående pants ihændehavelse af Jens Stigsen på Weyrupgård. Godset består af 5 bønder i Bregninge, 1 i Leby og 1 i Tranderup. ${ }^{37}$

Samme Jens Stigsen har, ligeledes i Kong Hans' tid, pantsat 1 gård i Bregninge til sognepræsten i Rise. ${ }^{38}$

Ifølge Kancelliets brevbøger af 17/8 1550 får »Thönnes Sture følgebrev ad gratiam til alle tjenere under Næsbyhoved len, som nu svarer Jørgen Brae og bo på Arre, at de herefter skulle svare ham til Synderborrig.« Det drejer sig dog her formentlig om det tidligere omtalte klostergods, som $\mathrm{i}$ en periode har ligget til Næsbyhoved len.

Christian 3. overdrager i 1536 to gårde på Ærø, som har tilhørt Peder Mogensen, borger i Svendborg, som imidlertid "nu er rømt af riget til vor og rigens fjender«, til Detleff Brockdorf, amtmand på Sønderborg slot. $^{39}$

Den ovenfor nævnte indenøs lavadelsmand Mats Lud, som i 1492 havde afhændet en gård i Tranderup til Helligåndsklostret i Fåborg, ejede i 1514 ifølge en skatteliste 3 gårde på Ærø, i henholdsvis Dunkjær, Tranderup og Skovby. ${ }^{40}$ I 1540 dømmes Mattis Lud ved kongens retterting til at udlægge to gårde, "den ene i Stokkeby, den anden $\mathrm{i}$ Riise», til Jørgen Quitzow. På det tidspunkt er Matz Lud bosiddende i gården "Skovsgård " på Langeland, som han har tilgiftet sig. ${ }^{41}$ Der er en påfaldende discrepans mellem beliggenheden af disse to gårde og oplysningerne i skattelisten fra 1514. Den gård, som i 1540 er anført til Rise kan dog være den samme, som i 1514 ligger i Dunkær i Rise sogn, mens gården i Stokkeby ikke genfindes i 1514. Er det en fejlskrivning for Skovby? Eller er Mattis Lud kommet i besiddelse af flere gårde i mellemtiden?

De omtalte gårde må før 1564 være kommet i Frederik 2.s besiddelse.

Dette ovennæunte adelsgods indgår i det gods, som overdrages til hertug Hans den Yngre i 1564.

Jacob Brockenhuus til Damsboe havde en del gods på Ærø, men Christian 3. mageskifter i 1555 med ham, så han får gods på Fyn til gen- 
gæld for 10 gårde på Ærø. Det drejer sig om 5 gårde i Olde, 1 i Skovby og 4 i Tranderup. ${ }^{42}$ Dette gods kommer ikke i hertug Hans den yngres besiddelse i 1564, men følger det ovennævnte, til kronen forfaldne klostergods. Vi kender ikke Jacob Brockenhuus' adkomst til dette gods. For en dels vedkommende kan det dreje sig om det gods, som ved reformationen ligger til Slesvig domkirke.

Den slesvig-holstenske adel:

Ifølge et tingsvidne fra Ærø dateret 23. juni 1442 pantsætter Hartvig Schack sit gods beliggende i Leby på Ærø til hertug Adolf af SlesvigHolsten »vor hundert syeder mark «. ${ }^{43}$

I et regnskab for 1638 for Søbygårds len er i marginen anført følgende notater vedrørende hertug Hans den Yngres opkøb af adeligt strøgods på Ærø: ${ }^{44}$

I Vindeballe: 1 gård fra Wulff von Alefeld i 1574 og 1 fra Siuert von Alefeld i 1584 .

I Tranderup: 1 gård fra Wulf von Alefeld i 1573.

I Olde: 1 gård fra Wulff von Alefeld i 1573 og 1 gård fra Siuert von Alefeld i 1584.

I Rise: 1 gård fra Wulf von Alefeld i 1573.

I Risinge (Lille Rise): 1 gård fra Sven Blome 1575.

I Dunkær: 1 gård fra Wulf von Alefeld i 1573 og 1 gård fra Siuert von Alefeld i 1584 .

I Leby: 1 gård fra Wulf von Alefeld i 1573, 1 gård fra Siuert von Alefeld i 1584 og 1 gård fra Detlef Sehested i 1587.

I Bregninge: 1 gård af Claus von Alefeld i 1573, 1 gård af Sven Blome i år? Og 1 gård af Siuert von Alefeld i 1584.

I Tranderup: 3 gårde og 2 indsiddere i 1590 af Hans Blome.

Den 1. febr. 1578 mageskifter Hans Blome 4 gårde på Ærø, 2 i Tranderup, 1 i Bregninge og 1 i Risinge (Lille Rise) med hertug Hans. ${ }^{45}$

Af et skøde fra 1584, hvori Siuert von Alefeld sælger sit (formentlig resterende) gods på Ærø til hertug Hans, ${ }^{46}$ fremgår, at det drejede sig om yderligere 1 gård $\mathrm{i}$ Olde, yderligere 1 gård $\mathrm{i}$ Vindeballe, yderligere 1 gård i Leby og 1 gård i Tranderup, 2 kådsteder i Leby, 2 kådsteder i Vindeballe samt Carl Brandt i Ærøskøbing, der betaler 3 skp. byg. 
I jordebogen 1627/28 står, at Wulf von Alefeldt har solgt en gård i Leby til hertug Hans. Det drejer sig antagelig om yderligere en gård i Leby, ud over den han afhændede i 1573.

Ovenstående må antages at være en komplet redegørelse for det gods, som hertug Hans den Yngre i årene 1570 til 1590 afkøbte af den slesvig-holstenske adel.

Med dette adelsgods, og det kloster- og adelsgods han 1584 definitivt modtog fra den danske konge, havde Hans den Yngre kompletteret sit ejerskab til Ærø.

\section{NOTER}

1. Svend Aakjær, (udg.): Kong Valdemars jordebog bd. I-III. 1926-45.

2. Vedrorende krongodset og dets opdeling i patrimonium og kongelev: Se Anders Leegaard Knudsen: Den danske konges gods $\mathrm{i}$ højmiddelalderen. Hist. tidsskr. 2, 1988 og Carsten Porskrog Rasmussen: Kronens gods. I: Danmark i Senmiddelalderen, red. Per Ingesman og Jens Villiam Jensen 1992, s. 80-81.

3. Erik Kroman: Marstals søfart. 1928, s. 12.

4. Dipl. Dan. II, nr. 283.

5. Erik Kroman: Da Ærø tilhorte markgreverne af Brandenburg. I: Froboen 37. årg. Nr. 4. 1969.

6. Arild Huitfeldt: Danmarks riges kronike, Chronologia II, s. 215. Genoptrykt $1977 \mathrm{Kbh}$.

7. Hofmann. Danske atlas VII. 450.

8. A. Leegaard Knudsen 1988, s. 227: "på et tidspunkt (måske efter borgerkrigene i 1130-erne) har kongerne valgt at opfatte noget gods som folgende kronen, måske navnlig byerne."

9. J.R. Hübertz: Beskrivelse over Ærø. 1834 , s. 80.

10. En fyldestgørende redegørelse for konflikterne vedrørende arvedelingen efter Chr. 3. hos Karsten Hermansen: Enkedronning Dorotheas og hertug Hans den Yngres kamp for kirkehøjheden over Als og Ærø 1566-1622. Sonderjyske årbøger. 1996, s. 65ff.
11. Registrering och forteignillse paa hues wrett, bröst och besueringer, som fougdene, presterne, capellaner, deignne och kircke thiennere paa Alsö och Errö beklagett haffuer. Inn aprilis anno 1605 . Indberetning indsendt $i$ henhold til Instrux for Lauritz Brockenhuus til Brangstrup og Mag. Jakob Madsen af 31. Juli 1589 angaaende deres Sendelse til Als og Ærø. Tyske Kancelli, ind. afd. A (1670), 98 I-II.

12. Sønderjyske Fyrstearkiver. De sønderborgske hertugers arkiv. Hertug Christian. RA.

13. Erik Kroman. 1928, s. 12.

14. Slesvigske Regnskaber. Kongens arkiv. Regnskaber over afgifter og skatter 1500-1514-1518-1524. RA.

15. Slesvigske regnskaber: Register over indtægt og udgift, afgift og skat af Sundeved, Als og Erø. RA.

16. Wolfgang Prange: Die Anfänge der grossen Agrarreformen In SchleswigHolstein bis zum 1771. Neumünster 1971, s. 371.

17. Sønderjyske Fyrstearkiver. Sager på papir. De sonderjyske hertugers arkiver. Plön. RA og Sonderjy. Fyrstearkiver. Sager på papir. De sønderjy. Hertugers arkiver. Glücksborg. H: Amtsskriver-kontoret på Gråsten. 16631710: Jordebøger og regnskaber for Gråsten amt. RA.

18. Erland Porsmose: i Atlas over Fyns kyst $\mathrm{i}$ jernalder, vikingetid og middel- 
alder. Red. Af Ole Crumlin-Pedersen, Erland Porsmose og Henrik Thrane. Odense universitetsforlag. 1996, s. 158.

19. Bjarne Porsmose: Selveje på Fyn. Odense universitet. 1982, s. 3-6. Specialeopgave. - "Atlas over Fyns kyst $i$ jernalder, vikingetid og middelalder. « Red. Af Ole Crumlin-Pedersen, Erland Porsmose og Henrik Thrane. Odense universitetsforlag. 1996, s. 158.

20. Jørgen Skaarup i J. of danish Archaeology vol. 12, 1994-95, s. 166: The large and diverse assemblage of finds, including about 125 coins, appears to assign the structure to a brief but intensive pereiod of use in the first half of the fourteenth century."

21. Reimer Hansen und Willers Jensen (Udg.): Quellen zur Geschichte des Bistums Schleswig. Quellensammlung der Gesellsch. f. Schl.-Holst. Gesch. 6. bd. 1904.

22. C.L.E.v. Stemann: Geschichte des öffentlichen und Privat-Rechts des Herzogthums Schleswig. Bind 3. Urkunden-Verzeichnis. Nr. 78: Arröer Dingswinde. Betr. Zuerkennung von Gütern an das Domcapitel. 17. März 1476.

23. Slesvigske Regnskaber. Amtsregnskaber Nordborg og Sonderborg. Regnskaber over afgifter og skatter 15001514-1518-1524. RA.

24. J. R. Hübertz: 1834, s. 56.

25. Rep. Dipl. Regni Dan. Mediev. II, nr. 3887 og 3888 og Slesvigske regnskaber: Register over indtægt og udgift, afgift og skat af Sundeved, Als og Erø. RA.

26. Kanc. Brevb. 24. sept. 1551.

27. Dipl. Dan. I, 6. nr. 62.

28. Rep. Dipl. Regni Danici mediev. II, nr. 2997.

29. Æ. da. Archivreg. Bd. 5, 2. del s. 183.

30. De sønderborgske hertugers arkiv. Hans d. Yngre. Akter vedr. striden mellem kongen og Hans d. Y. RA.
31. Rep. Dipl. Regni Dan. Mediev. II, nr. 11316: Foborgh helligåndskloster mageskifter til kongen gods på Allse, Erræ og i Bog herred for gods i Sallinge herred. Tyske Kancelli, ind. afd. A.V. 98-1: Akter vedr. Forhandlinger med enkedronning Dorothea og Hans den Yngre om den gejstlige jurisdiction på Als og Ærø m.m. 1567, 1571august 1573.

32. Se herom endvidere Kanc. Brevbøger 17/8 1550 og Kronens skøder, bind 1, s.d.

33. Æ. da. archivreg. Bd. 5, 1. del s. 11.

34. Tyske Kancelli, indl. afd. A.V. 98-1.

35. Dipl. Dan. II, 2, nr. 114.

36. Erik Kroman: Ærø under de første oldenborgske konger. I: Ærøboen, nr. 3. 1974.

37. Æ. da. archivreg. Bd. 5, 1. del, s. 1112.

38. Æ. da. archivreg. Bd. 5, 1. del s. 13.

39. Kancelliets brevbøger IV, 33b, 7/4 1536. Kronens skøder bd. 1, 7. apr. 1536.

40. Slesvigske regnskaber. Amtsregnskaber: Regnskaber for Sønderborg og Nordborg, 1500-1524. RA.

41. Det kgl. Rettertings domme og rigens forfølgninger fra Christian $3 . s$ tid, s. 506.

42. Kanc. Brevb. 20. febr. 1555.

43. C. L. E. Stemann. 1867. Bd. 3. Urkunde-Verzeichnis. Nr. 43: Dingswinde von Arrö über eine Verpfändung. 23. Juni 1442.

44. Sønderjyske Fyrstearkiver. Sager på Papir. De sønderjyske hertugers Arkiver. Pløn. 1634 - 43: Indtægts- og udgiftsregnskaber fra Søbygårds len på Ærø. RA.

45. De sønderjyske fyrstearkiver. Hertug Hans C 2: Forsk. adkomstbreve 15741621. Nr. 2.

46. Sønderjyske fyrstearkiver. De sønderborgske hertuger. Plønske rentekammer. Sager på papir. (3) Søbygårds len 1634-43. 